\title{
"Crouching Tiger, Hidden Dragon": the Representation of the Far East Countries in the Russian Caricatures of 1890-1905
}

\section{Anna I. Rezvukhina}

Biography Research Center "AITIA". Kaliningrad, Russia. Email: anya.rezvuhina[at]gmail.com

\section{Abstract}

This article is devoted to the zoomorphic images of China and Japan in the caricatures published in the Russian periodical press from 1890 to 1905. The aim of the study is to analyze the mechanisms of building images of the Other by creating a comic effect, as a strategy for overcoming cultural aphasia. The study focuses on the caricature technique of zoomorphism, or giving the Other an animalistic form. Within the framework of the article, we examined the possibilities of caricature as a means of political communication and analyzed its tools for expressing the changing political situation, including opportunities for the actual transformation of the image. In addition, the reception of zoomorphism as a shift in the natural/innate domain in the gradation from "prey", "noble animal" to "beast" was examined. According to the results of the study, the image of China as a dragon and the images of Japan as a dog or monkey as well as the symbolism of the yellow color and exotization as a method of alienation are of most interest. Furthermore, the issues of the imperial discourse of the Russian Empire, which was formed, among others, under the influence of the colonial discourse of the leading European powers of that time, the problem of orientalism as well as the question of self-identification of Russia within the framework of the "East-West" opposition, were discussed. The article is intended for everyone who is interested in the history of the development of political caricature in Russia and those who study the theoretical and practical issues of creation of the image of the Other.

\section{Keywords}

Image of the Other; the Other; Imagology; Imagema; Representation; Deconstruction; Orientalism; Caricature; China; Japan 


\section{«Крадущийся тигр, затаившийся дракон»: репрезентация стран Дальнего Востока в российских карикатурах 1890-1905 гг.}

\section{Резвухина Анна Ильинична}

Центр биографических исследований «AITIA». Калининград, Россия. Email: anya.rezvuhina[at]gmail.com

\section{Аннотация}

Данная статья посвящена рассмотрению зооморфных образов Китая и Японии в карикатурах, публикуемых в российской периодической печати с 1890 по 1905 год. В качестве материала исследования были использованы сатирические иллюстрированные журналы «Шут», «Будильник», «Осколки», «Стрекоза». Целью исследования является выявление механизмов выстраивания образов Другого посредством создания комического эффекта как стратегии преодоления культурной афазии. Изучается карикатурный прием зооморфизма, или же придания Другому анималистической формы. В рамках статьи мы рассмотрели возможности карикатуры как средства политической коммуникации и разобрали инструменты, которые используются для выражения меняющейся политической ситуации, в том числе художественные возможности актуальной трансформации образа. Подробно проанализировали прием зооморфизма как смещения в область природного / врожденного в градации от «добычи», «благородного зверя» до «чудовища». По итогам исследования, наибольший интерес представляют образ Китая в качестве дракона и образы Японии в качестве собаки или обезьяны, а также символика желтого цвета и экзотизация как метод отчуждения. Затронута тема великодержавного дискурса Российской империи, который формировался в том числе под влиянием колониального дискурса ведущих европейских держав того времени, проблема ориентализма, а также вопрос самоопределения России в рамках противопоставления «Восток - Запад». Статья предназначена для всех, кто интересуется историей развития политической карикатуры в России, и тех, кто исследует теоретические и практические вопросы построения образа Другого.

\section{Ключевые слова}

образ Другого; Другой; имагология; имагема; репрезентация; деконструкция; ориентализм; карикатура; Китай; Япония

Это произведение доступно по лицензии Creative Commons «Attribution» («Атрибуция») 4.0 Всемирная 
Galactica Media: Journal of Media Studies. 2021. No 3 | ISSN: 2658-7734

От карикатуры до интернет-мема | https://doi.org/10.46539/gmd.v3i3.189

\section{Карикатура и карта мира}

Человеку свойственно «давать имена» явлениям мира, визуализировать и вербализировать их, создавая определения и образы, соотносимые с оригиналом. Так происходит включение нового и неизвестного в уже сложившуюся картину мира, ее расширение. С помощью представлений люди осваивают и присваивает себе явления окружающей действительности, делают их понятными и «близкими», преодолевая разрыв между собой как познающими субъектами и ими как познаваемыми объектами. В том числе подобному освоению и приближению подлежит пространство как географическая единица, имеющая свои границы и характеристики.

На рубеже XIX и XX веков продолжалось расширение карты колониальных владений и зависимых от европейских держав территорий, равно как и расширение карты Российской империи, с целью включения в них Дальнего Востока (Китай, Корея, Япония). Дальневосточный регион оказался в центре внимания международной политики и стал ареной борьбы за сферы влияния для США, Российской империи и европейских держав, а также Японии, которая конкурировала с Россией, Великобританией, США и Германией за территории Маньчжурии. Стремительно возрастала интенсивность экономических, политических, культурных контактов. Разрозненных, субъективно окрашенных и недоступных для широкой публики экспедиционных дневников и заметок путешественников, которые исследовали Дальний Восток и лишь очерчивали эту «слепую зону» (Благодер, Минц, 2011, с. 117), было недостаточно для формирования массового представления о регионе. Возник запрос на восполнение данного пробела в общем имперском знании. Маркировать и вписать регион Дальнего Востока - буквально «нанести его на карту мира», включить в визуальную культуру Российской империи - предстояло медиа.

Под понятием медиа в указанный хронологический период имеется в виду пресса, периодические печатные издания, а именно - пришедшие на смену «толстым» журналам периодические газеты и журналы. Они стали ведущими медиа за счет своей относительной дешевизны, компактности, скорости печати и издания номеров, а также благодаря формату еженедельных и ежедневных выпусков, которые обеспечивали быструю реакцию на социальные, политические и культурные события. Помимо текстовых заметок и статей, над которыми работали журналисты, писатели и критики, в журналах могли размещаться визуальные сообщения - иллюстрации и карикатуры, созданием которых занимались профессиональные художники. Необходимо отметить, что периодика в конце XIX - начале XX века начала обретать масштаб средства именно массовой информации, то есть предназначалась для широкого круга читателей. Основную аудиторию представляли дворяне, а также образованное городское население: разночинцы, мещане, купечество. Большая часть населения Российской империи оставалась безграмотной (крестьяне). 
Увеличение аудитории газет и журналов коррелировало с ускорением урбанизации и ростом грамотности городского населения. Урбанизация была связана с ростом числа предприятий и увеличением численности городского населения за счет миграции бывших крестьян после отмены крепостного права; на повышение грамотности населения были направлены такие меры правительства, как открытие училищ, школ и библиотек для крестьян, книжное просвещение. Новый читатель был в первую очередь горожанином. Это задавало спрос на так называемую «малую» или «бульварную» прессу, которая должна была не только информировать, но и развлекать (рубрики городских сенсаций, анонсы культурных мероприятий, реклама). Карикатура также была инструментом для объединения развлекательного и информационного компонентов в периодике, благодаря чему формат сатирических иллюстрированных изданий к концу XIX века стал одним из наиболее востребованных.

Так как в фокусе данного исследования находится «российский взгляд» на Дальний Восток в карикатурах, аналитическая работа была сосредоточена на выпусках периодических изданий, выходивших на территории Российской империи с 1890 по 1905 год. Именно газеты и журналы выступили в роли площадок для выработки общедоступных, узнаваемых, понятных образов стран мало изученного пограничного рубежа. Это связано, с одной стороны, с тем, что описание дальневосточного региона вышло за рамки узкого круга специалистов: институтов - министерств, академий и университетов, а также отдельных людей - ученых, исследователей, путешественников, торговцев, офицеров, инженеров, писателей и других. Когда знание о Китае и Японии стало темой общественной дискуссии, власть монополизировала конструирование их образов, так как их содержание стало политическим (Фролов, 2016, c. 19). Перед государством стояла задача сформировать лояльное общественное мнение относительно российской политики на Дальнем Востоке, например, вмешательства России в Боксерское (Ихэтуаньское) восстание и раздел сфер влияния в Китае или ведения Русско-японской войны (Воробьева, 2007, с. 159), для чего необходимо было для начала объяснить и показать читателю, что такое Дальний Восток, что представляют из себя Китай и Япония.

С другой стороны, пресса охватывала большую часть информационного поля Российской империи, «газета на тот момент была самым доступным и относительно достоверным источником информации», а «ставший широко применяемым телеграф ускорил процесс обмена информацией» (Минин, 2019, c. 13). Скорость передачи новостей, их доступность, а также кредит доверия аудитории к печатным изданиям способствовали выдвижению газет и журналов в качестве основного канала культурного освоения и включения в общественную картину мира дальневосточного региона. Хотя каждое издательство имело собственную издательскую политику, которая определялась ожиданиями и, в первую очередь, политическими предпочтениями целевой аудитории, освещение темы Китая и Японии шло в рамках общего великодер- 
жавного дискурса Российской империи, который формировался в том числе под влиянием колониального дискурса ведущих европейских держав того времени, что очевидно также из частых заимствований вербальных и визуальных образов из сатирических журналов европейских метрополий и США. Необходимо отметить, что цензура газет и журналов «двух столиц», Москвы и Петербурга, была строже и жёстче, чем цензура «местной» периодики, издаваемой на российском Дальнем Востоке и в Сибири, которая допускала более свободный подход к конструированию образов Китая и Японии, создавая (насколько это было возможно в идеологических рамках того времени) альтернативу столичному повествованию о «Востоке», во многом за счет его меньшей экзотизации, чему способствовала географическая близость регионов, большее количество прямых экономических и культурных контактов.

Одним из эффективных инструментов «приближения» образа Дальнего Востока, который активно использовался в печатных медиа, стала карикатура. Сатирическое изображение было способно предоставить сжатое, ёмкое и доступное описание конкретной страны или целого региона, его населения и культурных особенностей, не выходя за рамки визуального ряда. Более того, использование не только текстовых, но и визуальных описаний расширяло охват аудитории медиа - «при низком уровне грамотности населения в России вплоть до начала XX в. визуальные образы не могли не занимать доминирующего положения в культурной коммуникации» (Щербакова, 2011, с. 479); карикатура удовлетворяла запрос публики, в особенности городской, скорее на развлекательные, нежели на аналитические материалы. Немаловажно также то, что карикатура откликалась на актуальные политические и общественные события, одновременно с тем опираясь на массив укоренившихся стереотипов, ассоциаций, визуальных ходов.

Ключевым моментом, на котором основана действенность карикатуры как способа построения образов неизвестного Другого, является то, что посредством юмора и соподчиненных ему средств художественной выразительности она хорошо выполняет функцию точной разметки на категории «свой / чужой». Происходит не только отражение географических и культурных реалий при помощи деталей образа, но и фиксация политических предпочтений: доселе неизвестные и потому нейтрально воспринимаемые страны получают четкое обозначение союзников или соперников, а действия собственной страны по отношению к тем или другим - легитимность. При выстраивании карикатурного образа различия между своей и чужой культурой либо сглаживаются, и тогда акцент идет на поиск схожих черт, либо, что происходит чаще, эти различия подчеркиваются и преувеличиваются, в том числе для достижения комического эффекта. То, что человек воспринимает как более понятное, близкое, родственное, похожее на него, имеет положительный смысловой заряд; чем дальше оно удалено от «своего», понимаемого как норма (Сенявский, Сенявская, 2006, с. 57), тем больше отторжение и неприятие, и потому имеет негативный заряд. Благодаря такой эмотивности 
карикатура является предельно простым и однозначным, хоть и насыщенным смыслами сообщением, ускоряет ориентирование в потоке информации.

Категории «Свой / Чужой» крайне важны в процессе освоения новых явлений, в том числе Другого (в качестве которого, например, выступает пространство с населяющими его народами) как неизвестного субъекта, так как эти категории задают модусы узнавания и принятия или узнавания и отвержения. В обоих случаях в Другом выискиваются знакомые и понятные черты, признаки сходства или чуждости, опасности, в зависимости от преобладания и признания за Другим скорее положительных (близких) или скорее отрицательных (чуждых) характеристик определяется его роль и место в соответствующей картине мира. Визуальные образы карикатуры, отражая стереотипы, в то же время фиксируют подобную культурную карту предпочтений и неприязни.

Представление о пространстве часто визуализировалось с помощью антропоморфных и зооморфных образов. Антропоморфные образы стран аллегоричны: местности могли изображаться в виде античных богинь с характерной узнаваемой атрибутикой государственных символов, вроде красного фригийского колпака Марианны-Франции, либо в виде собирательного образа Матери/Девы (Родины) также с яркими деталями, отсылающими к той или иной национальности, например, через традиционный крестьянский костюм или элементы повседневного быта. Такие устоявшиеся образы были у США и России, а также стран Европы. Антропоморфность, она же человекоподобность, уравнивала фигуры между собой, даже если изображался конфликт это был конфликт разумных и равных друг другу по статусу фигур.

Иначе дело обстоит с зооморфными образами: «зверинец» всегда предполагает иерархию. Если за антропоморфными существами имплицитно закрепляется возможность свободы выбора, способность к свободному мышлению и действию, то зооморфные фигуры связаны с укорененными в культуре представлениями о том или ином животном, за которым закреплены определенные - изначально человеческие - качества (например, трусливый заяц, хитрая лиса, верный пес). За счет смещения в животный мир эти качества трансформируются из приобретенных, каковыми являются у человека, во врожденные и неизменные. Выбор животного как основы карикатурного образа никогда не случаен: по сути, это животное-метафора, которое заключает в себе некое основное качество, избираемое как соответствующее народному характеру того или иного региона, раскрывающее его суть. Для закрепления связки «пространство - зооморфная фигура» для карикатуры выбирается животное, являющееся геральдическим символом или характерным представителем местной фауны.

Есть благородные и нечистые животные, полезные и вредные, примитивные и «почти разумные», есть хищники и их добыча. Так или иначе, иерархия в царстве животных, рассматриваемом с точки зрения человека, присутствует всегда. Таким образом, если Другой представлен зооморфно, ему 
автоматически приписывается определенный набор врожденных качеств и соответствующее место в геополитической пищевой цепочке.

Крайняя степень отчуждения Другого достигается в образе врага, полностью дегуманизированном, в котором отсутствуют человеческие черты (Сенявский, Сенявская, 2006, с. 63). Враг максимально далек от нормы, установленной «своей» культурой, с ним невозможно найти точки соприкосновения и схожие черты. В карикатуре эта крайняя точка отвержения воплощается в образе зверя/чудовища. Животное не уравнено в статусе с человеком, но его можно понять, приручить, спугнуть, в то время как чудовище агрессивно, враждебно, опасно, жестоко, неразумно, оно воплощает принцип насилия и аморальности, с ним невозможно договориться. Зооморфная фигура чудовища несет в себе черты максимальной чуждости; это нечто ненасытно хищное, фантастическое, экзотическое, принципиально инаковое. Если Другой предстает в облике чудовища, «то к нему неприменима человеческая мораль, нормы поведения, заповеди» (Дятлов, 2014, с. 31), он отныне «агрессор, варвар, садист, преступник, убийца» (Воробьева, 2018, с. 166), по отношению к которому санкционируется ответное насилие и агрессия. Применительно к чудовищу действенны лишь две тактики: укрощение и истребление, что на уровне общественного мнения узаконивает эксплуатацию, презрение, унижение, жестокость по отношению к врагу.

Так как колониальное соперничество на Дальнем Востоке к концу XIX века продолжало эскалировать, российской власти была необходима легитимизация собственных военных действий и участия в вооруженных конфликтах на данной территории, результатом чему стал небывалый по своей интенсивности процесс конструирования образов дальневосточных стран для первичного освоения и размещения в собственной картине мира, и постоянной их трансформации, вплоть до низведения до образа врага/чудовища, в связи с изменениями во внешнеполитических отношениях между странами.

Следующая часть исследования посвящена непосредственно рассмотрению зооморфных образов Китая и Японии в карикатурах, публикуемых в российской периодической печати с 1890 по 1905 год. Материалом для исследования послужили номера наиболее популярных сатирических иллюстрированных журналов за рассматриваемый период - «Шут» (издавался в Санкт-Петербурге с 1871 по 1878 год под названием «Маляр», затем под названием «Шут» с 1879 по 1914 год), «Будильник» (издавался в Санкт-Петербурге с 1865 по 1871 год, затем в Москве с 1873 по 1917 год), «Осколки» (издавался в Санкт-Петербурге с 1881 по 1916 год), «Стрекоза» (издавался в Санкт-Петербурге с 1875 по 1908 год, после перерыва с 1915 по 1918 год).

В качестве вспомогательного материала в исследовании используется анализ текстовых образов Китая и Японии на страницах газет и журналов, издававшихся как в Петербурге - «Летопись войны с Японией» (В.В. Фролов) и Москве - «Русские ведомости» (Т.М. Кудрявцева), так и «местных» изданий Сибири и Дальнего Востока, издававшихся в Томске - «Сибирская жизнь» 
(Э.А. Воробьева), «Сибирский вестник» (Н.А. Минин), в Иркутске - «Восточное обозрение» (Е.В. Севостьянова), во Владивостоке - «Дальний Восток» (Э.А. Воробьева).

\section{Китайский дракон}

Китай и Япония до определенной степени сохраняли для России статус terra incognita даже при возросшей интенсивности контактов и культурного обмена: в диковинку были местные обычаи, язык, одежда, прически и в целом внешний облик населения. Именно в связи с изначальным отсутствием у читателя какого-либо цельного представления о китайском и японском народах многие карикатуристы при построении образа этих стран использовали наиболее очевидный и простой ход - конструировали усредненный образстереотип «типичного представителя» Китая или Японии, за основу которого были выбраны китайский чиновник и японская гейша / японский солдат (подчеркнем, что эти образы «типичного» китайца или японки не соответствовали реальной репрезентации различных слоев населения Китая и Японии), при этом преувеличивались и всячески подчеркивались экзотичные для русского читателя черты и детали, в том числе гипертрофировалась внешность жителей Дальнего Востока. За счет подобной гиперболизации достигался желательный комический эффект, который можно было усилить, поместив экзотичную фигуру иностранца в ситуацию столкновения с русскими или европейскими реалиями.

Для Китая, например, таким антропоморфным образом в карикатурах стал чиновник с длинной косицей, одетый в непривычные для европейцев долгополые сложные одеяния, благодаря чему достигалась определенная феминность, ассоциативно связанная со слабостью, трусостью, глупостью, и, вместе с тем, с хитростью, двуличием, коварством. Необходимо отметить, что даже в антропоморфном образе активно используется прием частичного зооморфизма, когда человеческий облик деформируется, лицам намеренно придаются звероподобные черты, вместо ногтей изображаются длинные острые когти и т.д. Подобное изображение Другого, который за счет гипертрофированности отличий похож скорее на чёрта из славянского фольклора, нежели на человека, может служить в качестве переходной стадии к формированию собственно зооморфного образа.

Внимание к необычным, экзотическим, почти фантастическим для России элементам китайской культуры во многом предопределило выбор животногопервоосновы для конструирования зооморфорной фигуры этой страны. Наиболее частотным, превалирующим образом Китая в карикатурах периодической печати 1890-1905 гг. является дракон, весьма почитаемое фантастическое существо китайской космогонии (рис. 1). 


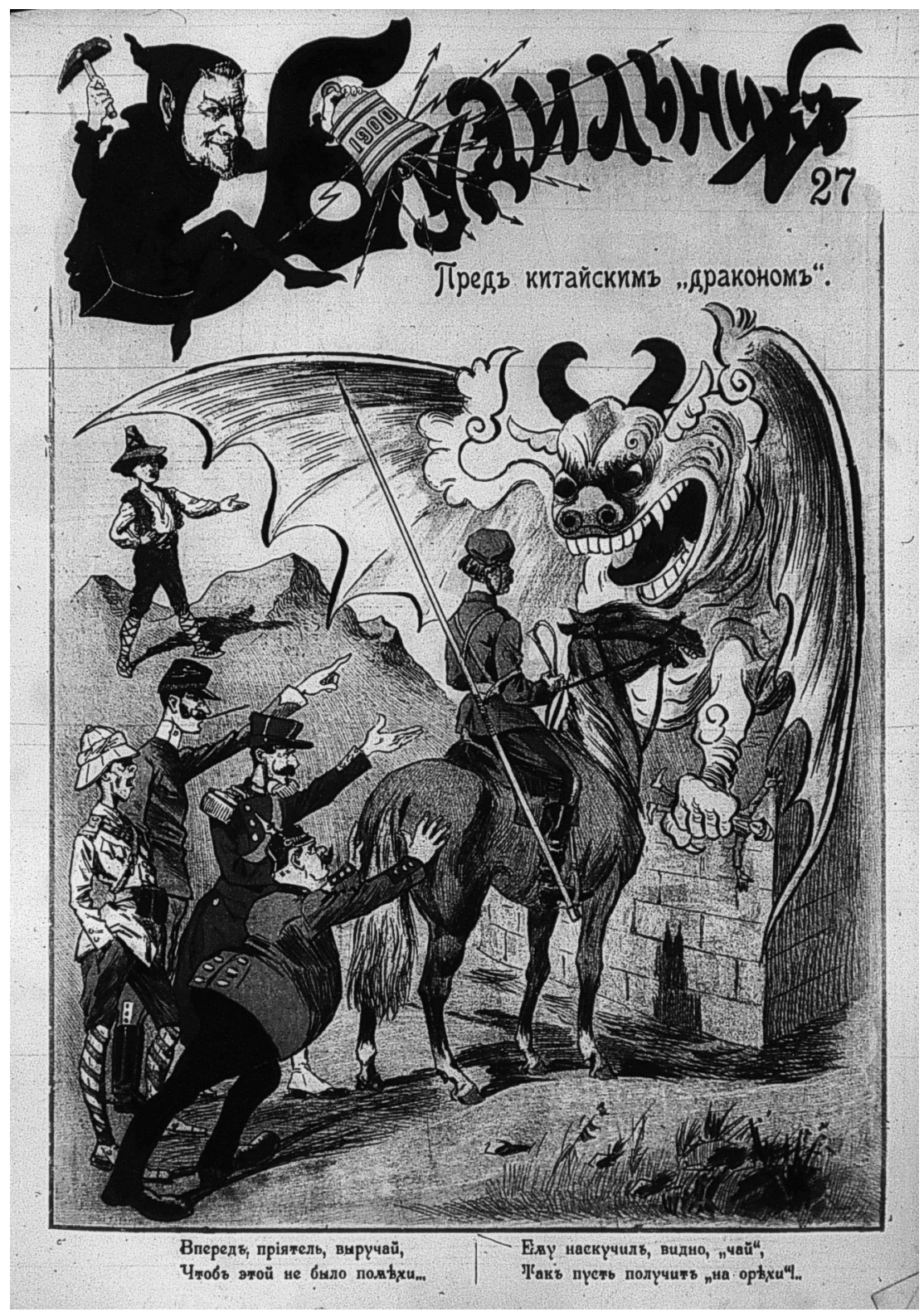

Рис. 1. «Пред китайским “драконом"», 1900

Fig. 1. " Facing the Chinese 'dragon,"' 1900.

Дракон (лун) играет чрезвычайно значимую роль в символическом пласте китайской культуры, которая «всегда самоопределялась как "культура дракона"» (Кобзев, Рифтин, 2006). В связи с этим может сложиться превратное впечатление, что при конструировании карикатурного образа Китая произошло прямое заимствование сложившегося автостереотипа. На самом деле в этом случае задействован куда менее очевидный ход, ставший возможным исключительно благодаря принципиальному различию европейской и китайской символики: заимствование внешней формы автостереотипа с присвоением диаметрально противоположного смыслового содержания. 
В Китае дракон входит в состав четырех божественных и священных существ, наравне с единорогом (цилинь), фениксом и черепахой; он ассоциируется с красотой, мощью, процветанием, развитием, счастьем и удачей (Кобзев \& Рифтин, 2006), с ним связаны представления о святости, мудрости, доброте, величии и благородстве, он также выступает в качестве символа государства и императорской власти. Китайский дракон - это, однозначно и без исключений, доброе и благородное существо.

Дракон в европейском понимании является прямой противоположностью вышеописанному существу и потому имеет совершенно иной ассоциативный ряд. Европейское, а вместе с ним и российское представление о таком фантастическом животном, как дракон, основывается на общей христианской традиции. В христианстве дракон, наряду со змеем, является одним из воплощений дьявола, источника всего зла и страданий на земле. Поэтому для христианских стран дракон - самое страшное из мифических чудовищ, воплощенный символ свирепости, жестокости, злобы, алчности, опасности, греховности; победа над драконом относится к традиционной героической символике. Благодаря подобной разнице восприятия, даже при прямом заимствовании внешнего облика китайского священного зверя-покровителя и без использования дополнительных приемов для снижения символического образа до комического, удалось создать полноценное изображение Другого как Чужого, со всеми сопутствующими негативными коннотациями, которые должны были подчеркнуть его инаковость и чуждость.

Дальнейшее развитие этого зооморфного образа шло за счет добавления комических элементов в исходный вариант. Это касалось, прежде всего, неадекватного отображения силы и мощи дракона. При достаточно детальном отображении внешнего вида могучего хищного чудовища, в том числе огнедышащей пасти, острых когтей и зубов, в большинстве случаев дракон изображается относительно небольшим, соразмерным человеческим фигурам или меньше их. Даже если дракон по размерам превосходит людей или изображен агрессивным, атакующим, угрожающим, другие персонажи на карикатуре, будь то антропоморфные фигуры или зооморфные, не выражают испуга или страха. Чаще всего дракон показан пассивным; спящим, побежденным, связанным, его загоняют в клетку, надевают намордник, сажают на цепь. При этом следует отметить, что эмоция, к которой апеллирует такое изображение, это не только торжество и злорадство, подпитанное чувством превосходства, но и жалость. Если на части карикатур дракон изображен гротескно уродливым или максимально приближенным к архетипичным образам из средневековых бестиариев, и сообщение карикатуры однозначно, то на других карикатурах он показан слабым и униженным, вызывающим скорее жалость, нежели презрение, так как в его взгляде, позе и внешнем виде акцентируется не столько звериное качество, сколько сходство с человеком, а у других персонажей, а именно - США и европейских стран - подчеркивается излишняя грубость и жестокость по отношению к уже побежденному существу. 
Эти акценты и апелляция к жалости читателя, конечно, не случайны: во время борьбы за сферы влияния на Дальнем Востоке со странами Европы и США отношение к Китаю было своего рода лакмусовой бумажкой, указывающей на «проевропейскую или противоевропейскую» позицию (Лукин, 2007, cс. 65-66).

Отношение к Китаю в интеллектуальных и даже властных кругах, задававших тон газетам, не было однозначным. Для проевропейски настроенных людей Китай представлял собой одряхлевшую, слабую деспотическую империю в упадке, служащую негативным примером для России и мира, в то время как для сторонников идеи особого пути России китайская цивилизация была положительным примером глубокой, богатой и при этом отличающейся от европейского образца культуры (Лукин, 2006, с. 22). Первый путь предполагал присоединение к общеевропейскому взгляду на Восток, утвердившемуся с конца XVIII века: в противовес Западу как единоличному носителю мирового прогресса и образцу вершинного развития в областях духовности, искусства, науки, техники, политики и экономики, Восток нарекался отсталым, косным, бесплодным, слабым и бесполезным (Лукин, 2006, c. 23), а его достижения культуры, история и традиции обесценивались, игнорировались или предвзято описывались «взглядом колонизатора», то есть как нечто примитивное, недоразвитое, неправильное. Из такой позиции проистекало, что восточным культурам следовало сделать «европейскую прививку», чем обосновывалась необходимость колониальных захватов. В противном случае пассивная громада воспринималась как препятствие, угроза для достигнутых западной цивилизацией высот.

Враждебность и принципиальная чуждость европейской цивилизации, которая виделась в Китае и Азии в целом странам Запада, легла в основу еще одного устоявшегося изображения Китая: в качестве спящего или пробуждающегося дракона. С одной стороны, этот образ олицетворял вялую, пассивную, неподвижную громаду, тот самый косный и застывший в своем развитии антипод активной Европе, находящейся всегда в движении на пути прогресса. С другой стороны, спящий или нет, дракон остается драконом; он воплотил в себе страх перед таящимся внутри китайской цивилизации потенциалом и силой, перед ее необъятностью, громадностью, многолюдностью. И здесь, конечно, можно заметить побуждение к действию через визуальный ряд нужно что-то сделать до того, как дракон проснется, обезопасить себя, подчинить его или заковать в цепи.

Второй путь развивался в рамках имперской идеологии «восточничества», поддерживаемой в том числе приближенным к императору Николаю II князем Э.Э. Ухтомским: согласно этой идеологии, Россия «по своим культурноисторическим особенностям была ближе восточным странам, чем к западным, и именно в Азии было ее будущее» (Суворов, 2015, с. 148). Особенно подмечались сходства между российским самодержавием и правлением императора в Китае, местным культом монарха и консерватизмом, патриархальность. 
За счет того, что «до середины XIX века Россия была единственной европейской державой, которую Китай признавал равной себе, подписывая с ней договоры и посылая дипломатические миссии» (Титаренко, 2014, с. 98), государственными деятелями и прессой активно культивировался миф о русскокитайской «вековой дружбе», исторической близости культур, добрососедских отношениях. Молодая Российская империя с этой позиции мыслилась в роли покровителя Китая, который еще не стал европейской колонией и не подпал под западное влияние, в роли «защитника Китая, выступающего на стороне мира и справедливости и не ищущим выгод для себя лично» (Старовойтова, 2019, с. 37), который мог бы установить свое покровительство мирным путем.

Обе позиции предполагали участие в колониальном подчинении китайских территорий, но по-разному очерчивали характер российской миссии на Востоке. Наравне с Европой, «русские политические и общественные деятели видели себя и Россию, в целом, некой силой, которая способна "цивилизовать косный и застывший Китай"» (Старовойтова, 2019, с. 36), присоединяясь к видению китайской культуры как нуждающейся в помощи со стороны, что способствовало легитимации активного вмешательства в жизнь китайских провинций. Но при этом столкновение с геополитическими интересами США, Японии и Европы на Дальнем Востоке вызывало у общественного мнения осуждение их жесткой колониальной политики, в противовес которой была сформулирована идея о «великодушной помощи» России, которая могла бы оградить Китай от западного влияния под своим протекторатом, установленным мирным путем за счет дипломатии.

Идея мирного влияния на Дальнем Востоке и колебания в системе «Запад - Восток» были пресечены участием России в вооруженном подавлении Боксерского (Ихэтуаньского) восстания, сильно ухудшившем отношения с Китаем. Россия присоединилась к общеевропейской колониальной агрессии и жесткому укрощению «китайского дракона».

\section{Двуликая Япония}

Как и в случае Китая, Япония воспринималась неоднозначно. Даже сильнее, нежели китайская, японская культура рассматривалась через призму своей причудливости и инаковости, под влиянием флёра диковинности, необычности и экзотичности этой страны и ее реалий. Представление о традиционной «живописной Японии» российская публика переняла у Европы вместе с модой на японизм в изобразительном и декоративноприкладном искусстве, литературе (Любимова, 2020, с. 155): Япония была страной изысканных и утонченных гейш, размеренных чайных церемоний, прекрасных расписных вееров, доблестных самураев, нежно-розовой сакуры, мелодичных хокку; страной - лаковой шкатулкой, полной изящных вещиц, страной-сказкой, застывшей в тихом и волшебном безвременье, о которой грезила мчавшаяся на всех парах прогресса Европа. 
Но вместе с тем «живописная Япония» была вписана в общее повествование о Востоке как о диком, отсталом, варварском, закостенелом, недоразвитом, что утверждало, в свою очередь, миссию западных стран как несущих свет просвещения и цивилизации на Дальний Восток. Так, в России Япония представлялась двуликой: ей любовались и восторгались в модусе живописной страны-диковинки, и ее же высмеивали, уничижали и обличали в модусе невежественной восточной страны-варвара. Негативный модус усиливался тем, что Япония активно проявляла себя на геополитической арене Дальнего Востока и участвовала в разделении сфер влияния, что не вписывалось в сконструированный в рамках колониального дискурса образ Азии как «спящей угрозы». Эти противоречивые образы Японии сосуществовали в российском общественном сознании; текущие события определяли, какой из модусов становился ведущим в тот или иной момент (Кисеева, 2014, с. 217).

Антроморфным изображением «живописной Японии» как страныдиковинки стала гейша. Эта фигура идеально согласовывалась с представлением о далекой стране-фантазии: хрупкая, изящная, утонченная женщина с «неземной» внешностью, в которой азиатские черты лица подчеркивались при помощи особого макияжа, с необычной и богато украшенной прической, в роскошном расписном кимоно, умеющая развлекать гостей интеллектуальной беседой, пением, танцем и игрой на музыкальных инструментах. Это максимально феминный (и, как было указано ранее - поэтому слабый, неопасный, хоть и коварный, соблазнительный) образ с эротическим подтекстом, ведь гейша - не жена и не часть семьи, а лишь экзотическое развлечение. Эмоциональный заряд влечения, желания приближал чуждое и экзотичное зрителю, придавал ему положительные черты.

По мере модернизации и милитаризации Японии посредством заимствования западных технических достижений и военных моделей, акцент на феминности в отношении этой страны постепенно снижается. Фигура гейши вытесняется образом военного с гиперболизированными, вплоть до уродливого, азиатскими чертами лица, одетого в европеизированную военную форму. В нем подчеркнута агрессия, алчность, бездумное повторение движений и действий европейцев - так происходит смещение антроморфных образов в область звериного и их замещение зооморфным, так как японский военный по своему внешнему виду в карикатурах начинает все более походить на обезьяну, а по поведению - на собаку, разучивающую новые трюки.

Формирование зооморфного образа Японии как Врага / Чужого было в рассматриваемый период особенно актуально для России ввиду обостряющегося конфликта между странами за зоны влияния на Дальнем Востоке, кульминацией которого стала Русско-японская война 1904-1905 годов. Так как восприятие Японии в целом было изменчивым и неустойчивым, крайне противоречивым, выборка карикатур представляет собой множество сосуществующих и быстро сменяющих друг друга зооморфных обликов. 
Интересным способом это сосуществование неустоявшихся образов иллюстрирует карикатура, на которой Япония изображена сразу в трех формах, как акула, омар и макака. Европа активно конструировала свои образы для Японии: «собака, райская птица, пчела, борец сумо» (Глазунова, 2013, сс. 50-51). Отметим также, что в европейских (особенно английских, журнал "Punch") карикатурах зооморфные образы России и Японии зачастую представлены агрессивными и дикими в одинаковой степени, что указывает на попытки исключить Россию из общеевропейского дискурса ввиду конфликта геополитических интересов.

Островное географическое положение и противостояние с Россией на море стало основанием для стратегии конструирования образа Японии как морского гада или рептилии: в карикатурах встречаются изображения морской жабы, акулы, осьминога, змеи. Их посредством акцентируются, помимо очевидной связи с водой, морем, такие характеристики, как прожорливость и непомерный аппетит, хладнокровие, скользкость (физическое качество переходит в личностное), хитрость. Чужеродность усиливается за счет выбора экзотических видов змей, лягушек и т.д. Осьминог, в качестве которого также часто изображалась другая морская держава - Великобритания, прочно ассоциировался с жадностью и захватническими интенциями (так как у него восемь щупалец, а у обычного человека - только две руки), что усиливало представление о Японии как о «стране, стремящейся не просто к победе в конкретной войне, а к господству в Азии и чуть ли не в мире» (Воробьева, 2007, сс. 159-160).

Чтобы подобный образ мировой угрозы выглядел скорее не устрашающе, а смешно, в карикатурах с изображением Японии (не только в виде спрута, но и в других зооморфных и даже антропоморфных образах) обыгрывается сюжет несоразмерности. Политические интересы и устремления Японии не соответствуют ее размерам. Другие страны, в том числе Россия и Китай, предстают значительно превосходящими ее по размерам, иногда элемент неравенства дополнительно усиливается за счет того, что иные фигуры представлены антроморфно, а Япония - в виде животного, насекомого, даже целого роя, стаи маленьких, но досаждающих, вредных существ, таких как комары или крысы. Тем не менее, Япония никогда не показана бессильной или пассивной; даже в самой уничижительно-малой форме она атакует и ведет себя агрессивно. Это отлично иллюстрирует выражение «желтокожие пруссаки» (Кудрявцева, 2011, с. 40) по отношению к японцам, которое одновременно апеллирует к виду тараканов и к наиболее милитаризированному государству Европы, известному своей военной мощью: Пруссии.

Несоразмерность и неравенство сторон усиливалось за счет сравнения физических данных представителей европейских стран и японцев, которые были ниже ростом, выглядели более хилыми в плане телосложения. Интересно, что японцы знали об этом «природном аргументе», который западными странами использовался для утверждения превосходства европейской цивилизации над Востоком (лозунг можно сформулировать так: «Европа изна- 
чально сильнее не только духовно, но и физически»). Поэтому «в картинах стиля нисикиэ, часто служивших пропагандистским целям, японцы <..> старались показать себя равными русским, доказать свою цивилизованность в глазах европейских держав» (Нахо, 2004, с. 108). В японских медиа использовался и аналогичный европейским карикатурам ход: фигуры японцев сознательно рисовались крупнее, в то время как в русских карикатурах они намеренно уменьшались.

После множества проб и трансформаций карикатура смогла создать два максимально емких, содержательных, легко читаемых образа Японии, которые впоследствии стали наиболее частотными - собаки и обезьяны. Оба они основаны на изначально положительном образе «"Японии-ученицы", жадно впитывающей основы европейской цивилизации» и ее наставницеРоссии (Тарасенко В., Тарасенко Т., 2014, с. 86), сформированных в 1880-е годы и отброшенных вместе с идеей установления мирного доминирования на Дальнем Востоке.

Желание Японии приобщиться к достижениям европейской культуры поначалу поощрялось и снискало однозначное одобрение со стороны Европы и США, так как подтверждало тезис о едином пути прогресса, на переднем рубеже которого находился Запад, и от которого якобы далеко отстал Восток. Снисходительность и поощрение, однако, быстро обернулась упреками в черной неблагодарности, когда Япония стала использовать приобретенные знания против самих европейских держав (что, по иронии, действительно сблизило ее в поведенческом плане с цивилизованным западным миром).

Отличной метафорой подобного неблагодарного поведения стала собака, «кусающая руку, которая ее кормит». Образ маленькой, беспородной собачонки, почти щенка, озлобленной, суетливой, прислуживающей за подачки, послушной и покорной только из-под палки, - воплощал представление о зависимости Японии от Европы, так как именно та учит ее разным трюкам, отдает команды. Вновь используется комический эффект преуменьшения, так как собака-Япония всегда изображается нелепой и преувеличенно небольшой в сравнении с антропоморфными и зооморфными персонажами других стран: к примеру, рядом с одним из традиционных образов Великобритании, крупным бульдогом, она действительно кажется щенком. С этим карикатурным образом связан сюжет нападения собаки на собственных хозяев, который обличает одновременно Японию и Европу.

Представление о зависимом, несамостоятельном, подражающем поведении, а также об обманутом доверии присутствует также в зооморфном образе Японии как обезьяны. Как было указано ранее, он во многом был создан посредством дегуманизации антроморфных образов Японии, частичной деконструкции человеческого облика с включением зооморфных черт, поэтому иногда сложно сказать, изображен ли на карикатуре человек с излишне гиперболизированными, почти анималистичными чертами, или нарисована обезьяна, но в человеческой одежде и с человеческим поведением. 
Этот образ наиболее уничижителен, так как сообщает идею о неполноценности японцев как неких «низших существ», промежуточного звена между человеком и приматами.

В более нейтральном ключе, карикатурная обезьяна воплощает в себе незрелость, по своему поведению она похожа на злого ребенка. Японцев действительно часто сравнивали с детьми, которые повторяют за более умными взрослыми: «как дети, они зачастую ленивы, непослушны, малообразованны, боятся всего нового, но любопытны; как всем детям, им необходимо воспитание и твердая рука взрослых» (Тарасенко \& Тарасенко, 2014, с. 85). Обезьяна легко сочетается с таким образом, она подвижна, умна, легко обучается и приспосабливается, но при этом она пакостит и вредничает, может быть лживой, жестокой, коварной, подлой (рис. 2).

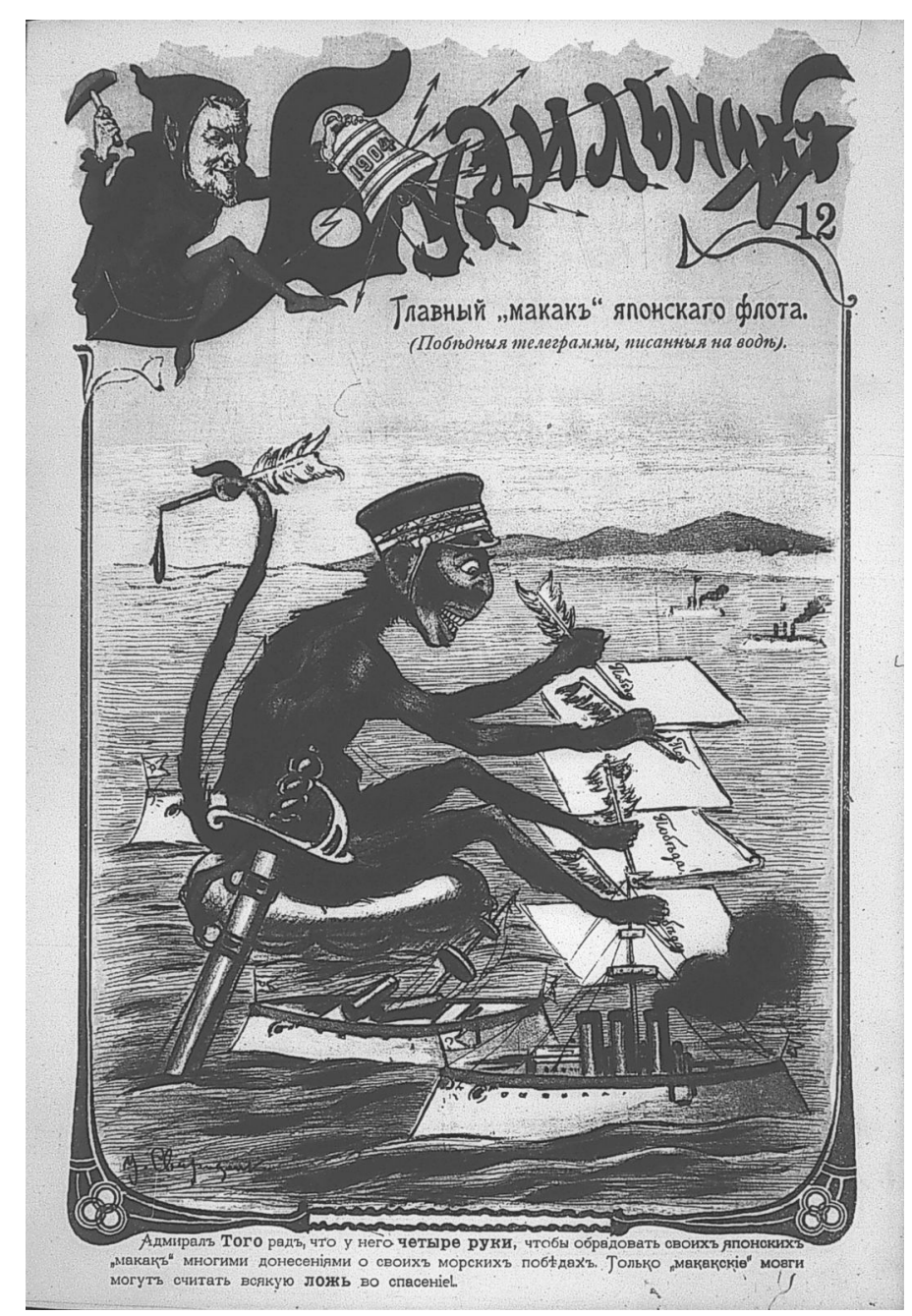

Рис. 2. «Главный “макак” японского флота. Победные телеграммы, писаные на воде», 1904

Figure 2. "Main "Macaca" of the Japanese Navy. Victory Telegrams Written on the Water," 1904 
Можно выдвинуть предположение, что образ Японии-обезьяны это своего рода химера. Этот получеловек сочетает в себе неразумное, вредное животное, низшее существо, которое, однако, обладает чертами, сближающими его с теми, кто стоит на более высоком уровне развития, стремится им во всем подражать, «обезьянничает». Химерность, двойственность образа подчеркивается сочетанием безобразных, искаженных звериной гримасой обезьяньих морд и европейской одежды, осуществлением обезьянами деятельности, обычно свойственной людям. Химера-Япония - это весьма продуктивный карикатурный образ, призванный отразить парадоксальность Японии как невообразимого сочетания полярностей «азиатского» / «традиционного» и «европейского» / «прогрессивного». Образ химеры, обезьяны обозначал противоестественность такого сочетания; формулировал представление о хитром, коварном, фантастическом чудовище, которое способно замаскироваться под «своих».

\section{Цвет: белый, жёлтый, красный}

Возросшие в XIX веке возможности полиграфии, в том числе развитие технологии печати, позволили использовать в карикатуре следующее важное визуальное средство: цвет. Пусть набор цветов все еще был довольно ограничен, стало возможным создание более «объемных» карикатурных образов. Отсутствие в палитре большого спектра оттенков и необходимость использовать преимущественно чистые цвета привели к выработке некоторых устойчивых сочетаний определенного цвета и значения; характерными для карикатурного образа становились не только детали, но и тона. Паттерны «цвет значение» опирались на традиционную для той или иной страны символику цвета, а избираемые карикатуристами сочетания и контраст добавляли изображаемому сюжету динамику. С выходом за пределы полярности монохромной картины мира, где черный и белый были либо сугубо функциональными, либо носили строго противоположные друг другу значения, смысловая нагрузка на цветовую плоскость увеличилась.

При рассмотрении образов Китая и Японии, выстроенных в рамках карикатурных изображений, по частотности на передний план, бесспорно, выходит желтый. Что примечательно, привязка к цвету в этом случае осуществлялась не только при помощи визуальных, но и за счет вербальных средств: за азиатским регионом со второй половины XIX века прочно закрепился ярлык «желтой опасности».

Обозначение «желтая опасность» или «желтая угроза» не возникло стихийно. Как очевидно из самой формы словосочетания (опасность/угроза для кого или чего? кому или чему угрожают?), этот ярлык был присвоен извне и не являлся частью самоопределения: он был закреплен за Азией европейскими странами. 
В первую очередь, конечно, маркер «желтый» отсылает к различиям во внешности представителей европеоидной и монголоидной рас, а именно к различию в оттенке кожи. Хоть концепция расовых отличий достигла своего апогея позднее в нацистской идеологии, уже в рассматриваемый период с 1890 по 1905 год она использовалась как способ «экзотизации», а вместе с тем - как способ смещения в категорию Чужого дальневосточных народов посредством самой их телесности (цвет кожи, разрез глаз, рост, телосложение и т.п.), превращая тело в некий показатель цивилизованности или же варварства (Гузей, 2013, с. 172). Чуждость на уровне телесности, которая воспринималась как нечто предопределенное природой и неизменное, указывала на коренное, непреодолимое различие между Европой и Азией. «Желтый» вобрал в себя и маркировал другие негативные характеристики внешности народов Дальнего Востока: низкорослость, слабость, женоподобность (противовесом к утвердившемуся положительному образу «белого» человека-европейца или американца, которым приписывались такие характеристики, как высокий рост, крепкое телосложение, сила).

В России понятие «желтые» использовалось как нейтральное обозначение народов Восточной Азии и в обыденной речи просторечия, образованных слоев общества, и в документах, публицистике, научных исследованиях (Дятлов, 2014, с. 24). Это понятие содержательно было довольно размытым и имело широкий диапазон использования, к «желтым» народам могли причислять исключительно китайское население, а могли и весь «желтый Восток», то есть Китай, Корею, Японию, Тибет, Монголию, Маньчжурию, Индокитай. Более того, «неопределенность концепта "желтый” осложнялась не только довольно широкой трактовкой самого термина, но и отсутствием четкого понимания расовой принадлежности народов Российской империи» (Гузей, 2013, с. 169), в которой даже многие дворянские рода гордились своим древним происхождение от татарских князей.

Т.е. изначально сигнификат «желтые народности» в российском информационном пространстве носило сугубо инструментальный характер для собирательного обозначения народов Азии. «Желтый» приобретал свою негативную окраску постепенно, с усилением массового беспокойства по поводу «желтой угрозы».

Идея цивилизационного врага, синдром «желтой угрозы», также были характерны прежде всего для Европы, и оказались переняты Российской империей впоследствии. Данное явление возникло в середине XIX века и подпитывалось представлениями о «затаившейся угрозе», исходящей от Китая и Японии, которые потенциально могли нарастить экономическую и военную мощь и вступить в прямую конфронтацию с европейским и североамериканским миром. В качестве первых шагов «тихого захвата» иногда обозначался факт того, что китайские и корейские временные рабочие и переселенцы занимали рабочие места на территории России и США в ходе трудовой иммиграции (Коновалова, 2011, сс. 74-75). Закрепление идеи «желтой опасности» и всплеск 
ксенофобии в отношении китайцев в России произошли уже после Боксерского (Ихэтуаньского) восстания в пограничном Китае (Гузей, 2011, с. 82) и определения правительством основного вектора на экономическую экспансию для закрепления зон влияния.

Демонизацией желтого цвета окончательно устанавливалось представление о принципиальной несовместимости «белого» и «желтого» миров; усиливались расовые предрассудки, происходила дегуманизация противника. Властвующая элита решила для себя данный вопрос в пользу принадлежности Российской империи к культуре «белой Европы» и необходимости разделить роль защитницы христианской цивилизации перед лицом восточного варварства наравне с другими западными державами. Однако позиция самого Запада в оценке места России на мировой карте была неоднозначна: Европа «представляла ее или элементом "желтой опасности", или же плацдармом на ее пути к Европе» (Кисеева, 2014, с. 219).

Другой цветовой парадокс заключается в том, что желтый цвет в самом Китае является цветом императора, это цвет богатства и счастья: «Никто, кроме императора, не имел права носить одеяния желтого цвета. Поэтому все, что окружало Сына Неба, было исключительно желтого цвета: одежда, мебель, архитектурные сооружения и предметы интерьера» (Королева, Валеев, 2017, с. 111). В некоторых трактовках желтый цвет олицетворяет центр мира, то есть, саму Поднебесную. Как и в случае с образом дракона, столь активно используемом в карикатурах на тему «желтой угрозы», произошло прямое заимствование значимого для китайской культуры символа с придачей ему совершенно противоположных, негативных значений. Так Запад притворился, что говорит на языке Востока, совершенно его при этом не понимая, а лишь имитируя.

Завершая часть исследования, посвященную цвету в карикатурах, которые представляют образы Китая и Японии, хотелось бы остановиться на одном курьезном «цветовом» моменте. Как было обозначено ранее, Россия оказалась в сложном положении при необходимости выбора принадлежности между белой и желтой расой. Если Европа видела Российскую империю скорее в желтом спектре, а Азия, наоборот, в белом, то у Японии было в запасе еще одно неочевидное решение этого вопроса: среди японских образов России как Другого можно обнаружить привязку к красному цвету.

Так, в XVIII-XIX веках, задолго до событий Русско-японской войны, русских в Японии стали называть «акаэдзо» - «красные северные люди (варвары)», причем соотнесение с красным цветом («ака») произошло, по различным версиям, из-за розовощекости русских людей, наличия красного цвета в их обмундировании или лисьего меха как элемента одежды (Нахо, 2004, с. 114; Тарасенко, 2014, сс. 88-89). Вслед за произошедшим в 1806-1807 годах так называемом «инциденте Хвостова» ${ }^{1}$ с атаками российских

1 Также известен как Инцидент Резанова-Давыдова-Хвостова в России и как Российское вторжение годов Бунка в Японии - эпизоды военных инцидентов с самовольными атаками российских кораблей под командованием Николая Хвостова и Гавриила Давыдова на японские промыслы и селения на Сахалине 
военных на японские поселения после неудачных торговых переговоров, через ассоциативный ряд красного цвета «русский» стал дополнительным значением к японскому слову «акаони», которое обозначало демона-великана с красной кожей и острыми клыками, когтями и рогами из японской мифологии: «это демон, приносящий такие болезни, как оспа, скарлатина или корь, а также демон, похищающий детей» (Тарасенко, 2014, сс. 88-89).

Этот момент вновь подчеркивает несовпадение культурных кодов; красный цвет, в русской культурной традиции считавшийся благоприятным и воплощающим символы красоты, радости, жизни, власти, света, во взгляде со стороны, из другой традиции, обернулся цветом демоническим, несчастливым, агрессивным.

\section{Азия глазами Европы}

Подводя итоги проведенного исследования, хотелось бы отметить, что при рассмотрении политической карикатуры как инструмента первичного освоения культурного пространства становится очевидным, что конструируемый карикатурный образ указывает не только на представления об описываемом объекте, но и на самопредставление. При новом моделировании карты мира отчетливо очерчивается «мы»-перспектива, в которой Другой конструируется по формулам «от обратного» или «по схожести»: «"Свое” есть точка отсчета для восприятия чужого, "матрица" для сопоставления, мерило и критерий для оценки. Соотнесение, сопоставление, сравнение своего и чужого - основной механизм формирования образа иного» (Сенявский \& Сенявская, 2006, с. 59). Исходной точкой для описания стран Дальнего Востока всегда выступает Россия, шире - Россия в контексте европейской цивилизации.

«Свои» необязательно должны быть отражены в карикатуре напрямую, в виде какого-либо антропоморфного или зооморфного образа. Статус Другого или Чужого (врага) сам по себе является отражением «своего» в кривом зеркале, через призму отрицания и отчуждения определенных черт как несвойственных «нам», но свойственных Другому, или через подмечание общих черт. Иногда в этом отражении может присутствовать собственный автостереотип Другого, его представление о себе, если в карикатуре он показан методом деконструирования исходного символа, но опять же мы видим его глазами иной культуры.

Что касается отображения Азии и Европы в карикатурах, ключевым представляется их принципиальная противопоставленность, выражающаяся в таких оппозициях, как: сильное / слабое, мужское / женское, светлое / темное, белое / желтое, положительное / отрицательное, чистое / грязное, разумное / глупое, активное / пассивное, правильное / неправильное и т.д.

и Итурупе в 1806-1807 годах после провала переговоров по установлению торговых связей между Российской империей и сёгунатом Эдо. 
Использование этих оппозиций становилось одним из основных способов разграничения мира. Из-за эффекта диковинки, чрезвычайной экзотичности, возводимой в абсолют, Европа видела и отмечала в Азии скорее отличия, нежели искала общие с собой черты, что привело к представлению о коренных различиях, конфликтующих ценностях и идеалах, принципиальной несовместимости между ними. Экзотизация, хоть и полная восторга поначалу, послужила «механизмом отстранения и остранения», исключения и даже дегуманизации (Дятлов, 2014, с. 26). Это, в свою очередь, привело к нивелированию образа Другого до врага, чудовища, Чужого, который подлежит осмеянию, уничижению и уничтожению, так как, исходя из «мы»-перспективы, под культурой-нормой, «правильной» культурой понималась только лишь западная культура.

В такой парадигме мыслили не только США и европейские державы, но и Российская империя; впоследствии даже Китай и Япония начали отчасти оценивать себя и других через призму понятий о «азиатскости» и «европейскости», соответствия заданной западным миром норме. Поиск самоидентификации велся в пределах этих категорий, между Востоком и Западом, несмотря на то, что уже в рассмотренных нами карикатурных образах Китая и Японии прослеживается неоднородность самого понятия «Восток», очевидна «дихотомия двух образов Востока - прогрессивной, динамично европеизировавшейся Японии и застывшего, упрямого в своем консерватизме Китая» (Севостьянова, 2019, с. 66), которые сами по себе свидетельствовали о несводимости этих стран к какому-либо единому образу «Востока» и невозможности «упаковать» многообразие китайской и японской культур в усеченные, стереотипные представления, которые лишь свидетельствовали о глубоком непонимании внутренних процессов, происходивших в Китае и Японии в указанный период, а также нечитаемости для условного «Запада» их культурного кода.

Эти образы Китая и Японии как Чужих были релевантны исключительно для Европы, США и Российской империи как некие собирательные типы противостоящей им «неполноценной» и чуждой цивилизации, угрожавшей, реально или мнимо, их мировому статусу первенства среди держав. Восток был сконструирован и изображен через призму колониального и имперского дискурсов; скорее чем реалии китайской или японской культур, рассмотренные нами карикатуры отражают самопредставление Европы, США и России и их геополитические амбиции, выраженные через фигуру Другого. Обращение в XXI веке к образам Азии, которые возникли на стыке XIX и $\mathrm{XX}$ веков, актуально с той точки зрения, что хоть за более чем сто лет Китай и Япония стали ведущими экономиками мира, высокотехнологичными и развитыми странами, чьи обновленные образы скорее связаны с положительными коннотациями, в них все еще преломляются рудиментарные элементы прежнего дискурса, в том числе принципиальная инаковость и экзотичность (основанная теперь не на «старинности и традиционности», а на «футуристичности» 
Азии), которые продолжают препятствовать адекватному восприятию этих стран, культивируя разграничение «Запад - Восток».

\section{Благодарности}

Данная статья является частью исследования “The Russian Imagological Bestiary: the Zoomorphic Image of the Enemy (the Other) at the Turn of the Century, 1890-1905", проводимого совместно с Сергеем Александровичем Троицким, к. филос. н., и Алёной Ильиничной Резвухиной, магистром философии.

\section{Список литературы}

Благодер, Ю. Г. \& Минц, С. С. (2011). Образ Китая в сознании российского образованного общества XVII начала XX в. Вестник Российского университета дружбы народов. Серия: История России, (3), 110-126.

Воробьева, Э. А. (2007). Образ Японии и японцев в прессе Дальнего Востока и Западной Сибири в годы Русско-японской войны: Сравнительный анализ. Вестник Новосибирского государственного университета. Серия: История, филология, 6 (1), 159-163.

Воробьева, Э. А. (2018). «Прекрасная страна Япония, прекрасная страна Россия»: Формирование и восприятие образа врага. Идеи и идеалы, 1 (1), 164-182. doi: 10.17212/2075-0862-2018-1.1$164-182$

Главный «макак» японского флота. Победные телеграммы, писаные на воде. (1904). Будильник (Сатирический журнал с каррикатурали), 40 (12), 1.

Глазунова, Г. Б. (2013). Русско-японские отношения в начале XX века на страницах журнала «Панч»: Сатира и реальность. Грамота, (11-2), 50-52.

Гузей, Я. С. (2011). Боксерское восстание и синдром «желтой опасности»: Антикитайские настроения на российском Дальнем Востоке (1898-1902 гг.). Известия Алтайского Государственного Университета, (4-2), 82-86.

Гузей, Я. С. (2013). Категория «Желтые» в контексте расового дискурса в российской империи в конце XIX - начале XX в. Известия Иркутского государственного университета, серия: Политология. Религиоведение, (2-2), 67-178.

Дятлов, В. И. (2014). Экзотизация и «Образ врага»: Синдром «Желтой опасности» в дореволюционной России. Идеи и идеалы, 1 (2), 23-41.

Кисеева, Е. О. (2014). Образ Японии в российском общественном сознании (1875-1917).

Китай: история и современность: материалы VII международной научно-практической конференции, 217-225. Екатеринбург: Издательство Уральского университета.

Кобзев, А. И. \& Рифтин, Б. Л. (2006). Лун. Извлечено от Синология.Ру website: https://www.synologia.ru/a/\%D0\%9B\%D1\%83\%D0\%BD

Коновалова, О. С. (2011). Формирование термина «Желтая экспансия» относительно образа Китая в средствах массовой информации. Вестник Российского университета дружбы народов, серия: Литературоведение, журналистика, (3), 74-81. 
Королева, А. С. \& Валеев, Р. М. (2017). Интерпретация образа дракона в системе декоративноприкладного искусства и быта Китая. Вестник Казанского государственного университета культуры и искусств, (2), 108-113.

Кудрявцева, Т. М. (2011). Образ Японии в газете «Русские ведомости» (1895-1902 гг.). Вестник РГГУ. Серия: Литературоведение. Языкознание. Культурология, (6), 37-48.

Лукин, А. В. (2006). Эволющия образа Китая в России и российско-китайские отношения (XVIII-XX в8.) (Автореферат диссертации на соискание ученой степени доктора исторических наук). Москва.

Лукин, А. В. (2007). Медведъ наблюдает за драконом. Образ Китая в России в XVII-XXI веках. Москва: Восток-Запад.

Любимова, Н. С. (2020). Образ Японии в России - старые элементы в новом оформлении. Вестник антропологии, (3), 153-167. doi: 10.33876/2311-0546/2020-51-3/153-167

Минин, Н. А. (2019). Образ врага на страницах «Сибирского вестника» в период русско-японской войны. Материалы 57-й Международной научной студенческой конферениии, 13-14. Новосибирск: Новосибирский национальный исследовательский государственный университет.

Нахо, И. (2004). Взаимные образы русских и японцев (по фольклорным материалам). Вестник Евразии, (1), 95-121.

Пред китайским «драконом». (1900). Будильник (Сатирический журнал с каррикатурами), 36 (27), 1.

Севостьянова, Е. В. (2019). «Дряхлый Восток заставил говорить о себе...»: Китай и Япония на страницах газеты «Восточное обозрение» в последней четверти XIX в. Российско-Китайские Исследования, 3 (3), 62-75. doi: 10.17150/2587-7445.2019.3(3)

Сенявский, А. С. \& Сенявская, Е. С. (2006). Историческая имагология и проблема формирования «Образа врага» (на материалах российской истории ХХ в.). Вестник РУДН: История России, (2), 54-72.

Старовойтова, Е. О. (2019). Влияние китайско-японской войны 1894-1895 гг. на формирование образа Китая в России. Modern Oriental Studies, 1 (3), 29-39.

Суворов, В. В. (2015). Образ Китая в культурно-исторической и геополитической концепции «Восточничества». Симбирский научный вестник, (1), 148-150.

Тарасенко, Т. В. \& Тарасенко, В. Е. (2014). Визуализация образа русского и японца на плакате и карикатурах времен русско-японской войны. PR и реклама: традищии и инновации, (14-1), 83-92.

Титаренко, А. С. (2014). «Русско-китайская дружба» и особое отношение китайцев к русским: Стереотипы восприятия второй половины XIX - начала XX вв. Россия и Восток: культурные связи в прошлом и настоящем: материалы Международной научной конференции (IX Колоснищынские чтения), 98-103. Екатеринбург.

Фролов, В. В. (2016). Образ врага на страницах журнала «Летопись войны с Японией». Вестник Псковского государственного университета. Серия: Социально-гуманитарные науки, (4), 19-22.

Щербакова, Е. И. (2011). Визуальная история: Освоение нового пространства. В Г. А. Бордюгов (Ред.), Исторические исследования в России - III: Пятнадиать лет спустя (сс. 473-488). Москва: АИРО XXI. 


\section{References}

Blagoder, Y. H. \& Mints, S. S. (2011). Image of China in Consciousness of Russian Educated Society of the 17th - Early 20th Centuries. Bulletin of the Peoples' Friendship University of Russia. Series: History of Russia, (3), 110-126. (In Russian).

Chief "Macaque" of the Japanese Navy. Triumphant Telegrams, That Limn On the Water. (1904). Budilnik (Satiricheskij zhurnal s karrikaturami), 40 (12), 1. (In Russian).

Dyatlov, V. I. (2014). Exotization and "the Enemy Image": the Syndrome of "Yellow Peril" in Pre-Revolutionary Russia. Ideas and Ideals, 1 (2), 23-41. (In Russian).

Frolov, V. V. (2016). The Image of the Enemy in the "Chronicle of the War with Japan" Journal. Bulletin of Pskov State University. Series: Social and Humanitarian Sciences, (4), 19-22. (In Russian).

Glazunova, G. B. (2013). Russian-Japanese Relations at the Beginning of the 20th Century in Magazine "Punch»: Satire and Reality. Gramota, (11-2), 50-52. (In Russian).

Guzei, Ya. S. (2011). The Boxer Rebellion and the "Yellow Peril": the Anti-Chinese Moods on the Russian Far East (1898-1902). The Proceedings of the Altai State University, (4-2), 82-86. (In Russian).

Guzei, Ya. S. (2013). The Category of "Yellow" within the Context of Racial Discourse in Russian Empire at the End of the 19th - the Beginning of the 20th Centuries. The Proceedings of the Irkutsk State University, Series: Political Science. Religious Studies, (2-2), 67-178. (In Russian).

In Front of the Chinese "Dragon". (1900). Budilnik (Satiricheskij zhurnal s karrikaturami), 36 (27), 1. (In Russian).

Kiseeva, E. O. (2014). The Image of Japan in the Russian Public Consciousness (1875-1917). China: History and Modernity: materials of the 7th International Scientific and Practical Conference, 217-225. Екатеринбург: Издательство Уральского университета. (In Russian).

Kobzev, A. I. \& Riftin, B. L. (2006). Lun. Retrieved from Sinologia.ru website: https://www.synologia.ru/a/\%D0\%9B\%D1\%83\%D0\%BD (In Russian).

Konovalova, O. S. (2011). Formation of the Term "Yellow Peril" on the Image of China in the Media. Bulletin of the Peoples' Friendship University of Russia. Series: Literary studies, journalism, (3), 74-81. (In Russian).

Koroleva, A. S. \& Valeev R. M. (2017). The Interpretation of the Image of the Dragon in the System of Chinese Arts and Crafts and Mode of Life. Bulletin of Kazan State University of Culture and Arts, (2), 108-113. (In Russian).

Kudrjavceva, T. M. (2011). The Image of Japan in the Newspaper "Russian Vedomosti" (1895-1902). Bulletin of the Russian State University of Humanities. Series: Literary Studies. Linguistics. Culturology, (6), 37-48. (In Russian).

Lukin, A. V. (2006). The Evolution of the Image of China in Russia and Russian-Chinese Relations (18-20th Centuries) (Author's abstract of Doct. dissertation). Moscow. (In Russian).

Lukin, A. V. (2007). The Bear is Watching the Dragon. The Image of China in Russia in the 17-21th centuries. Moscow: East-West. (In Russian).

Lyubimova, N. S. (2020). The Image of Japan in Russia - Old Elements in a New Arrangement. The Anthropology Bulletin, (3), 153-167. doi: 10.33876/2311-0546/2020-51-3/153-167 (In Russian). 
Minin, N. A. (2019). The Image of the Enemy on the Pages of the "Siberian Vestnik" during the RussianJapanese War. Materials of the 57th International Scientific Student Conference, 13-14. Novosibirsk: Novosibirsk National Research State University. (In Russian).

Naho, I. (2004). Mutual Images of Russians and Japanese (Based on Folklore Materials). Eurasia Review, (1), 95-121. (In Russian).

Senyavsky, A. S. \& Senyavskaya, E. S. (2006). The Historical Imagology and the Problem of Building of "The Enemy's Image" (on the Materials of Russian History of the 20th Century). Bulletin of the Peoples' Friendship University of Russia. Series: History of Russia, (2), 54-72. (In Russian).

Sevostyanova, E. V. (2019). “The Shriveled Orient Made All Talk about Itself...": China and Japan in Columns of the Newspaper "Vostochnoye Obozreniye" in the Last Quarter of 19th Century. Russian-Chinese Studies, 3(3), 62-75. doi: 10.17150/2587-7445.2019.3(3).62-75 (In Russian).

Sherbakova, E. I. (2011). Visual History: Exploration of New Spaces. In G. A. Bordyugov (Ed.), Historical Studies in Russia - III: Fifteen Years Later (pp. 473-488). Moscow: AIRO XXI. (In Russian).

Starovoitova, E. O. (2019). Influence of the Sino-Japanese War (1894-1895) on the Image of China in Russia. Modern Oriental Studies, 1 (3), 29-39. (In Russian).

Suvorov, V. V. (2015). Image of China in the Cultural, Historical and Geopolitical Concept of "Easternism". Simbirsk Scientific Review, (1), 148-150. (In Russian).

Tarasenko, T. V. \& Tarasenko, V. E. (2014). Building the Image of Russian and Japanese on Posters and Caricatures during Russian-Japanese War. PR and Advertising: Traditions and Innovations, (141), 83-92. (In Russian).

Titarenko, A. S. (2014). «"Russian-Chinese Friendship" and the Special Attitude of the Chinese to the Russians: Stereotypes of Perception of the Second Half of the 19th - early20th Centuries. Russia and the East: Cultural Ties in the Past and Present: Materials of the International Scientific Conference (IX Kolosnitsyn Readings), 98-103. Yekaterinburg. (In Russian).

Vorobyeva, E. A. (2007). The Image of Japan and the Japanese in the Far East and Western Siberia Press During the Russian-Japanese War: a Comparative Analysis. Vestnik of Novosibirsk State University. Series: History, Philology, 6 (1), 159-163. (In Russian).

Vorobyeva, E. A. (2018). "The Beauteous Country, Japan; the Beauteous Country, Russia”: the Paradoxes of the Formation and Perception of the Enemy "Pattern Image". Ideas and Ideals, 1(1), 164-182. doi: 10.17212/2075-0862-2018-1.1-164-182 (In Russian). 